\title{
Trophic status of the restored South-West and non-restored East Beira Lakes
}

\author{
A.I.Kamaladasa and Y.NA.Jayatunga \\ Depariment of Zoology, University of Colombo, Colombo-03.
}

Revised: 01 January 2007 ; Accepted: 14 February 2007

\begin{abstract}
This study was carried out in the restored South West and non-restored East Beira Lakes, with the objectives of determining their current trophic status and investigating the effects of restoration in the South-West Lake with respect to selected water quality parameters.
\end{abstract}

Thirteen (13) stations in the South-West Lake and forty five (45) stations in the East Lake were sampled from 14.02.2005 to 17.03 .2005 . The mean values of the investigated parameters of South-West Lake and East Lake respectively are as follows: $\mathrm{pH} 9.3 \pm 0.5$ and $8.8 \pm 0.5$, electrical conductivity $0.35 \pm 0.03 \mathrm{~ms}$ $\mathrm{cm}^{t}$ and $1.8 \pm 0.4 \mathrm{~ms} \mathrm{~cm}^{-1}$, Secchi depth $14.5 \pm 1.5 \mathrm{~cm}$ and $12.5 \pm 1.6 \mathrm{~cm}, \mathrm{PO}_{4}^{3-}-\mathrm{P}$ (orthophosphate) $0.21 \pm 0.04 \mathrm{mg} \mathrm{L}^{\prime}$ and $0.52 \pm 0.2 \mathrm{mg} \mathrm{L}^{-1}, \mathrm{NO}_{3}-\mathrm{N} 1.5 \pm 0.07 \mathrm{mg} \mathrm{L}^{-1}$ and $1.3 \pm 0.2 \mathrm{mg} \mathrm{L}^{-1}$, $\mathrm{NO}_{2}-\mathrm{N} 0.01 \pm 0.02 \mathrm{mg} \mathrm{L}^{-1}$ and $0.14 \pm 0.2 \mathrm{mg} \mathrm{L}^{-1}$, chlorophyll-a $0.4 \pm 0.1 \mathrm{mg} \mathrm{L}^{-1}$ and $0.59 \pm 0.2 \mathrm{mg} \mathrm{L}^{-1}$. All investigated parameters showed significant differences between the restored and nonrestored sections of the lake during the period of study.

According to the of Organization for Economic Cooperation and Development (OECD) Fixed Boundary System, the trophic status of both the South-West and the East Lake were found to be hypereutrophic. The level of hypereutrophy according to the Carlson Trophic State Index based on chlorophyll-a content and Secchi disc depth was significantly lower in the restored SouthWest Lake when compared to the non-restored East Lake. However, the restoration objectives with respect to chlorophyll-a and Secchi disc depth were not achieved in South-West Lake.

Key words: Beira Lake, restoration, trophic status.

\section{INTRODUCTION}

Water bodies located in urban areas are generally recipients of municipal and industrial waste waters which lead to their deterioration. A good example of such a water body in Sri Lanka is the Beira Lake $\left(6^{\circ} 45^{\prime}-7^{\circ} 00^{\prime} \mathrm{N} 79^{\circ} 30^{\prime}-79^{\circ} 55^{\prime} \mathrm{E}\right)$, in Colombo city which is the commercial capital of the country.
Beira Lake was constructed in 1521 by Portuguese rulers to defend the fort of Colombo and it was a magnificent water body in its colonial past. Deterioration of the Lake started in the latter part of the $19^{\text {th }}$ century with reclamation of sections of the Lake for various constructions and with the use of the Lake to discharge municipal and industrial waste water ${ }^{1}$. At present, the Beira Lake is essentially a stagnant water body which is dependent on the run-off of its highly urbanized catchment, which covers approximately $448 \mathrm{ha}^{1}$. The bulk of the run-off into the Lake is provided by the rainfall which is highly variable due to the monsoonal effects ${ }^{1}$. In addition, there are many surface drains opened to the Lake, that bring unwanted discharges. The present extent of the Beira Lake is 65.4 ha which constitutes four main sections; East Lake (43.3 ha), Galle Face Lake (2.6 ha), West Lake (8.1 ha) and South-West Lake (11.4 ha) ${ }^{1}$.

Restoration and management of eutrophic water bodies located in urban centres are prioritized in the socioeconomic agenda of the central and local governments ${ }^{2}$. Neglected and deteriorated Beira Lake located in the heart of the country's commercial capital diminishes the aesthetic beauty of the city. Therefore it became an issue of concern to the government of Sri Lanka. Restoration of the Lake started in 1995 with the aim of "transforming the Lake and its environment into an attractive feature with recreational and social facilities" "3. The Beira Lake Restoration is one of the projects identified under the Colombo Environment Improvement Project ${ }^{3}$.

Under the above project restoration in the SouthWest Lake was completed and officially opened to the public in December, 2004. Restoration in the East Lake commenced in January 2005 (personal communicationSri Lanka Ports Authority). According to the Sri Lanka 
Ports Authority the restoration activities carried out in the South-West Lake are; dredging of the Lake bottom sediment, pumping of sea water from the adjacent sea and closing of much of the surface drains.

This study was conducted two months after the completion of restoration in the South-West Lake and one month after commencing dredging activities in the East Lake. The main objectives of the study were to determine the trophic status of the restored South-West Lake and the non-restored East Lake and whether the restoration objectives were achieved in South-West Lake. The effects of restoration activities on selected water quality parameters were determined by comparing data from pervious studies in South-West Lake with data of non-restored East Lake obtained during the present study. Data collected during this study for the non-restored East Lake can be used as baseline data which could be compared with data, following restoration.

\section{METHODS AND MATERIALS}

Sampling was carried out from $14^{\text {th }}$ February to $17^{\text {th }}$ March 2005. Forty five stations from East Lake (EL) and thirteen stations from South-West lake (SWL) were randomly selected for sampling. The number of stations was taken to be approximately one station per hectare of surface area in each section of the Lake. All Stations were reached by a motorboat provided by Sri Lanka Port Authority. Sampling was performed between $9.00 \mathrm{a} . \mathrm{m}$. and $11.00 \mathrm{a} . \mathrm{m}$. The approximate locations of the sampling stations are given in Figure 1.
At each station water samples were collected from the surface using a two litre Ruttner sampler of $0.5 \mathrm{~m}$ height. Water samples were then transferred into 21 pre-washed plastic cans for laboratory analysis of selected physicochemical parameters and into $250 \mathrm{~mL}$ plastic nontransparent bottles for the analysis of chorophyll-a. Secchi depth was measured at each sampling station using a $20 \mathrm{~cm}$ diameter Secchi disc. Water samples were transported to the laboratory within two hours of collection.

Immediately after transportation to the laboratory, direct measurements were taken for $\mathrm{pH}$ ( $\mathrm{pH}$ meter -Model :HM-1K, TOA Electronics, Japan) and electrical conductivity (conductivity meter-Model: Dist 3 HI98303, Hana Instruments).

Water samples were filtered through $\mathrm{GF} / \mathrm{C}$ filter papers to remove the green colour interference of algae and the nutrient concentrations were determined with standard sepctrophotometric methods; orthophosphate as $\mathrm{PO}_{4}{ }^{3-}-\mathrm{P}$ by Vanadomolybdophosphate method, nitrate as $\mathrm{NO}_{3}-\mathrm{N}$ by UV screening method and nitrite as $\mathrm{NO}_{2}-\mathrm{N}$ by Colorimetric method ${ }^{4}$.

To determine the cholophyll-a concentration a maximum filterable amount of water was filtered through $\mathrm{GF} / \mathrm{F}$ filter paper of $2.5 \mathrm{~cm}$ diameter and the algae retained on $\mathrm{GF} / \mathrm{F}$ pad was extracted into Acetone ${ }^{4}$. The optical density of the extract was measured at wave lengths $664 \mathrm{~nm}, 647 \mathrm{~nm}$ and $630 \mathrm{~nm}$ using a spectrophotometer

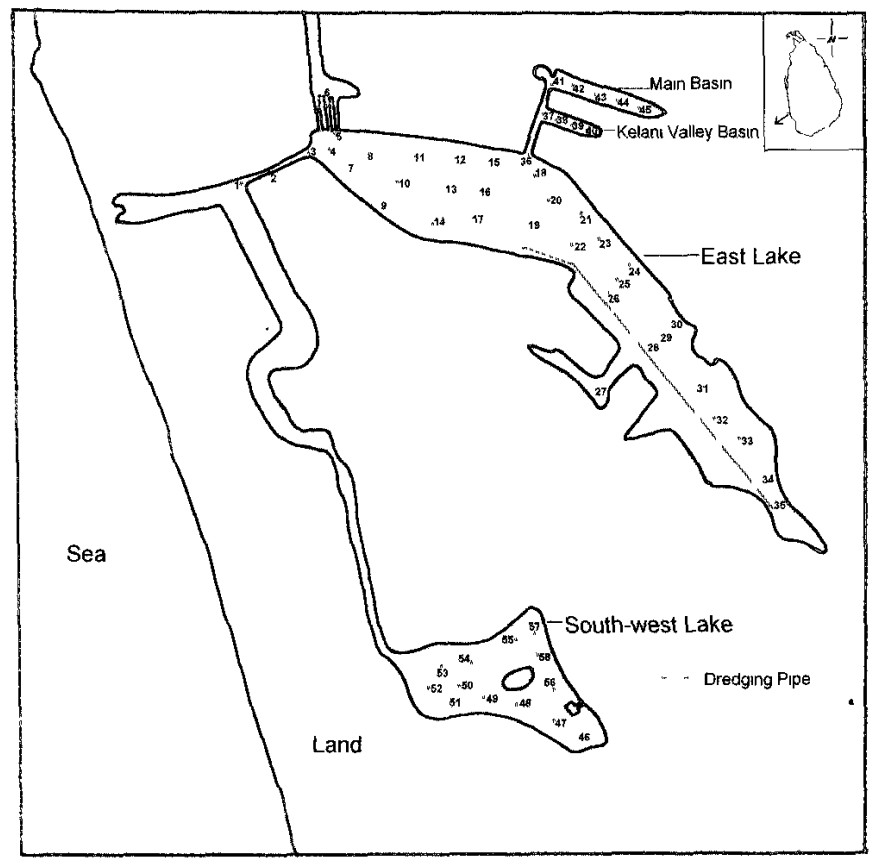

Figure 1: Approximate locations of the sampling stations 
(Model: PIN 260-14600-01 Shimadzu corporation, Japan) and the chlorophyll-a concentration was computed according to the following equation ${ }^{4}$.

Chlorophyll- $a$ content $\left(\mathrm{mgL}^{-1}\right)=$

$$
\left[\left(11.85 \mathrm{OD}_{664}\right)-\left(1.54 \mathrm{OD}_{647}\right)-\left(0.08 \mathrm{OD}_{630}\right) * \mathrm{v}\right.
$$

$\mathrm{V}$

$\begin{aligned} O D_{X} & - \text { Optical density at specified wavelengths } \\ V & - \text { Volume of the extraction in litres } \\ V & - \text { Filter volume in litres }\end{aligned}$

A correlation analysis was performed between chlorophyll- $a$ and the three tested nutrients, $\mathrm{PO}_{4}{ }^{3}-\mathrm{P}$, $\mathrm{NO}_{3}-\mathrm{N}$ and $\mathrm{NO}_{2}-\mathrm{N}$ using the software MATLAB.

The trophic status of South-West Lake and East Lake was evaluated using the Organization for Economic Cooperation and Development (OECD) Fixed Boundary System.

To compare the differences in trophic status of East Lake and South-West Lake, the Carlson Trophic State Index (TSI) based on chlorophyll-a (Chl-a) concentration
(Equation 2) and Secchi disc depth (SDD) (Equation 3) were calculated according to the following equations:

TSI $\left(\right.$ chl-a) $=9.81$ in chlorophyll-a $\left(\mu \mathrm{gL}^{-1}\right)+30.6$

$\mathrm{TSI}(\mathrm{SDD})=60-14.41$ in SDD (metres)

A t-test was performed using MINITAB software to determine the significant differences in investigated water quality parameters and the computed trophic status of the South-West and East Lakes.

\section{RESULTS}

The mean levels of the investigated physicochemical parameters of the South-West and East Lake and results of performed t-tests are given in Table 1.

With respect to all the parameters investigated, statistically significant differences were evident between the South-West Lake and the East Lake (Table 1). In SouthWest Lake, levels of Secchi depth, $\mathrm{pH}$ and $\mathrm{NO}_{3}-\mathrm{N}$ were significantly higher $(\mathrm{p}<0.05)$ while electrical conductivity, $\mathrm{PO}_{4}{ }^{3-}-\mathrm{P}$ (orthophosphate), $\mathrm{NO}_{2}-\mathrm{N}$ and chlorophyll-a were significantly lower $(\mathrm{p}<0.05)$ compared to East Lake.

Table 1: Mean \pm SD (ranges in parenthesis) of selected water quality parameters in South-west Lake and East Lake and computed $P$ values of $t$ - tests

\begin{tabular}{|l|c|c|c|}
\hline physicochemical parameters & $\begin{array}{c}\text { South-West Lake } \\
\text { Mean } \pm \text { SD } \\
\text { (range) }\end{array}$ & $\begin{array}{c}\text { East Lake } \\
\text { Mean } \pm \text { SD } \\
\text { (range) }\end{array}$ & p-Value \\
\hline Secchi depth (cm) & $14.5 \pm 1.5$ & $12.5 \pm 1.6$ & $0.001^{*}$ \\
& $(14-19)$ & $(8-14.5)$ & \\
\hline $\mathrm{pH}$ & $9.3 \pm 0.1$ & $8.8 \pm 0.5$ & $0.000^{*}$ \\
& $(8.9-9.7)$ & $(8.2-9.7)$ & \\
\hline Electrical conductivity $\left(\mathrm{ms} \mathrm{cm}^{-1}\right)$ & $0.34 \pm 0.03$ & $1.85 \pm 0.4$ & $0.000^{*}$ \\
& $(0.30-0.39)$ & $(0.54-2.14)$ & \\
\hline $\mathrm{PO}_{4}{ }^{3-}\left(\mathrm{mgL}^{-1}\right)$ & $0.21 \pm 0.03$ & $0.52 \pm 0.2$ & $0.000^{*}$ \\
& $(0.13-0.26)$ & $(0.15-0.99)$ & \\
\hline $\mathrm{NO}_{3}-\mathrm{N}\left(\mathrm{mgL}^{-1}\right)$ & $1.51 \pm 0.06$ & $1.3 \pm 0.06$ & $0.000^{*}$ \\
& $(1.37-1.62)$ & $(0.99-1.93)$ & \\
\hline $\mathrm{NO}_{2}-\mathrm{N}\left(\mathrm{mgL}^{-1}\right)$ & $0.01 \pm 0.02$ & $0.14 \pm 0.2$ & $0.000^{*}$ \\
& $(0.003-0.08)$ & $(0.002-0.74)$ & \\
\hline${\text { Chlorophyll-a }\left(\mathrm{mgL}^{-1}\right)}^{0.40 \pm 0.1}$ & $0.59 \pm 0.2$ & $0.000^{*}$ \\
& $(0.28-0.68)$ & $(0.33-1.28)$ & \\
\hline
\end{tabular}

*indicates significant differences at $\mathrm{p}<0.05$ 
All sampling stations were alkaline with respect to $\mathrm{pH}$. Electrical conductivity, $\mathrm{PO}_{4}{ }^{3-}-\mathrm{P}$ (orthophosphate), $\mathrm{NO}_{3}$ $\mathrm{N}, \mathrm{NO}_{2}-\mathrm{N}$ and chlorophyll-a varied within a narrow range in South-West Lake while the same in East Lake varied within a wider range (Table 1 ).

Orthophosphate concentrations less then $0.3 \mathrm{mgL}^{-1}$ were recorded for all stations in South-West Lake. In East Lake, except in five stations, orthophosphate concentrations were above $0.3 \mathrm{mgL}^{-1}$ (Figure 2).

High $\mathrm{NO}_{3}-\mathrm{N}$ concentration (above $1.4 \mathrm{mgL}^{-1}$ ) were recorded from all stations in South-West Lake. In East Lake, only nine stations out of 45 recorded $\mathrm{NO}_{3}-\mathrm{N}$ concentrations above $1.4 \mathrm{mgL}^{-1}$. Five out of the nine were confined to the distal end of the Lake (Figure 3). Very high levels of $\mathrm{NO}_{2}-\mathrm{N}$ were observed only from a few sampling stations of East Lake. These stations were confined to two areas of the Lake: (i) the distal end of the Lake (stations 31-35) (ii) the Kelani Valley Basin and in the canal connecting of the Kelani Valley Basin and Main Basin (stations 36-41). Very low $\mathrm{NO}_{2}-\mathrm{N}$ concentrations (below $0.05 \mathrm{mgL}^{-1}$ ) were recorded from most of the

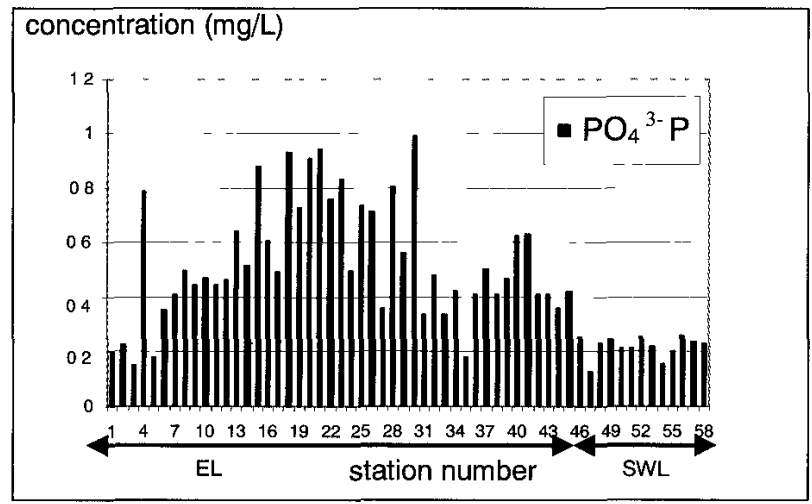

Figure 2: Concentration of $\mathrm{PO}_{4}{ }^{3-}$ in sampling stations during the study period

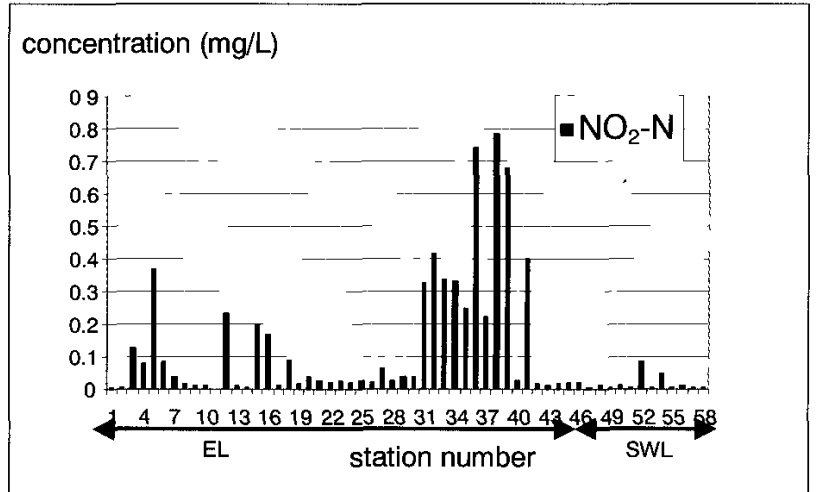

Figure 4: Concentration of $\mathrm{NO}_{2}-\mathrm{N}$ in sampling stations during the study period sampling stations of East Lake and from all stations of South-West Lake (Figure 4).

The chlorophyll-a concentration from all stations of both East Lake and South-West Lake were recorded above $0.2 \mathrm{mgL}^{-1}$. However in $66 \%$ of the stations ( 30 out of 45 stations) in East Lake and $7 \%$ of stations (1 out of 13 stations) in South-West Lake the chlorophyll-a concentrations were above $0.5 \mathrm{mg} \mathrm{L}^{-1}$ (Figure 5).

Chlorophyll-a concentrations showed significant correlations with $\mathrm{PO}_{4}^{3-}-\mathrm{P}$ (orthophosphate) and $\mathrm{NO}_{3}-\mathrm{N}$ concentrations. the correlations was positive with $\mathrm{PO}_{4}{ }^{3-}-\mathrm{P}$ (orthophosphate) $(\mathrm{p}<0.05, \mathrm{r}=+0.3696, \mathrm{n}=58)$ while it was negative with $\mathrm{NO}_{3}-\mathrm{N}(\mathrm{p}<0.001, \mathrm{r}=-0.6347$, $\mathrm{n}=58)$. No significant correlation was evident between concentrations of chlorophyll-a and $\mathrm{NO}_{2}-\mathrm{N}$ $(\mathrm{p}>0.05, \mathrm{r}=-0.2492, \mathrm{n}=58)$.

When the mean and maximum chlorophyll-a concentration and mean and minimum Secchi depth levels of South-West Lake and East Lake were compared with

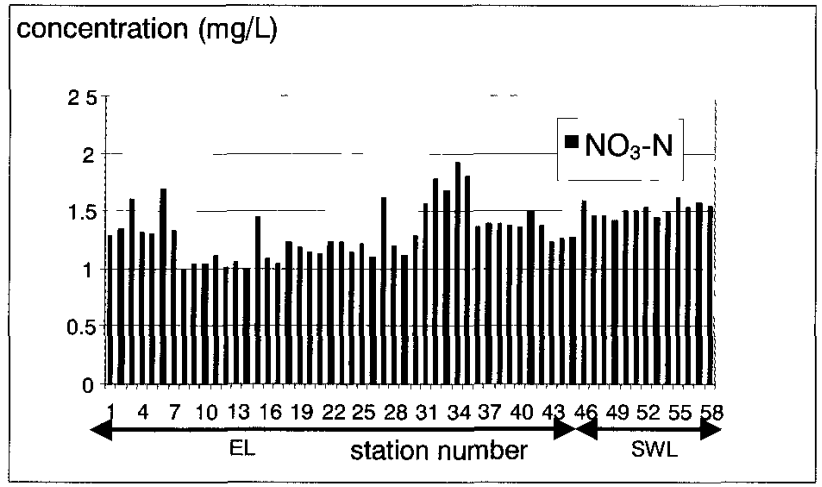

Figure 3: Concentration of $\mathrm{NO}_{3}-\mathrm{N}$ in sampling stations during the study period

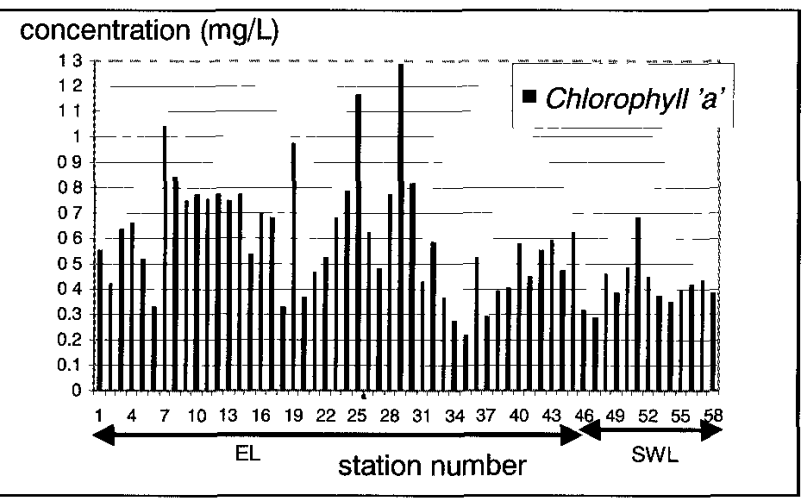

Figure 5: Levels of chlorophyll-a in sampling stations during the study period 
Table 2: The chlorophyll-a and secchi depth levels of the South-West and East lakes and the hypercutrophic limits according to Fixed Boundary System of OECD

\begin{tabular}{lccc} 
& South-West Lake & East Lake & Hypereutrophic limits \\
\hline Mean total phosphorous (mgL & & $\geq 0.1$ \\
Mean chlorophyll-a $\left(\mathrm{mgL}^{-1}\right)$ & - & $0.59 \pm 0.2$ & $\geq 0.025$ \\
Maximum chlorophyll-a $\left(\mathrm{mgL}^{-1}\right)$ & 0.68 & 1.28 & $\geq 0.075$ \\
Mean secchi depth $(\mathrm{cm})$ & $14.5 \pm 1.5$ & $12.5 \pm 1.6$ & $\leq 150$ \\
Minimum secchi depth $(\mathrm{cm})$ & 13 & 8 & $\leq 70$ \\
\hline
\end{tabular}

Table 3: TSI (Chl-a) and TSI (SDD) values of South-West Lake and East Lake and computed p values of $\mathrm{t}$ - test

\begin{tabular}{lccc}
\hline & South-West Lake & East Lake & p value \\
\hline TSI (Chl-a) & 89 & 91 & $0.001^{*}$ \\
TSI (SDD) & 88 & 90 & $0.000^{*}$ \\
\hline
\end{tabular}

Asterisk indicates significant differences at $\mathrm{P}<0.05$

the OECD ${ }^{5}$ Fixed Boundary System, the trophic status of both sections of the Beira Lake were found to be hypereutrophic. The chlorophyll-a concentration and Secchi depth levels of the two sections of the Lake and the respective hypereutrophic limits according to $\mathrm{OECD}^{5}$ are given in Table 2 .

The mean orthophosphate concentration of East Lake was $0.52 \pm 0.2 \mathrm{mg} \mathrm{L}^{-1}$ and of the South-West Lake was $0.21 \pm 0.03 \mathrm{mg} \mathrm{L}^{-1}$. Orthophosphate is only one constituent of the total phosphorous. Therefore it could be assumed that total phosphorous in both lake sections are above $0.1 \mathrm{mgL}^{-1}$, which is the hypereutrophic limit according to the $\mathrm{OECD}^{5}$ (Table 2).

The TSI (Chl-a) and TSI (SDD) values for SouthWest Lake and East Lake and the $p$ values of the performed $t$-test are given in Table 3 . According to the computed TSI (Chl-a) and TSI (SDD), the trophic status of South-west Lake was found to be significantly lower $(p<0.05)$ than East Lake.

\section{DISCUSSION}

Based on the OECD Fixed Boundary System, trophic status of both the already restored South-West Lake and the non-restored East Lake were found to be hypereutrophic. In a study done in 1994 using the same classification system, the Beira Lake was classified as being between eutrophic and hypereutrophic ${ }^{7}$. Therefore, a change in the trophic status is evident in both SouthWest Lake and East Lake. However, a significantly lower trophic level in South-West Lake compared to East Lake is evident according to both TSI (Chl-a) and TSI (SDD).
This indicates that South-West Lake is less hypereutrophic than East Lake which could be a result of restoration.

The expected Secchi depth and chlorophyll-a content at the end of restoration was $50 \mathrm{~cm}$ and $0.1 \mathrm{mgL}^{-1}$ respectively ${ }^{3}$. Mean Secchi depth of $14.5 \pm 1.5 \mathrm{~cm}$ and mean chlorophyll-a concentration of $0.4 \mathrm{mg} \mathrm{L}^{-1}$ recorded from South-West Lake in the present study reveals that restoration objectives with respect to parametets concerned have not been achieved.

The main feature that reduces the attractiveness of Beira Lake as a recreational and social facility is the dark green colour of water. Even after restoration, the green colour of the South-West Lake was persistant. This green colour is due to large algal blooms suspended in water (unpublished thesis, University of Colombo - Study of selected physiochemical parameters and plankton in East Lake, and South-West Lake of Beira Lake). According to the Biological Environment Survey carried out in 1993 before the commencement of restoration in South-west Lake, the average level of chlorophyll-a concentration was $0.269 \mathrm{mgL}^{-18}$. Therefore, an increase in chlorophyll-a level in South-West Lake at present is observed even though it is significantly lower than the non-restored East Lake section of the Beira lake.

When comparing the present orthophosphate levels of the South-West Lake $\left(0.21 \pm 0.03 \mathrm{mgL}^{-1}\right)$ with previous records; $0.4 \mathrm{mgL}^{-1}$ in $1993^{8}$ and $0.31 \mathrm{mgL}^{-1}$ in $1994^{7}$, a reduction in orthophosphates in the lake is evident. In studies conducted before restoration, the orthophosphate level was higher in the South-West Lake compared to East Lake ${ }^{7,8}$. But at present after restoration the level of 
orthophosphate is significantly lower in the South-West Lake compared to East Lake. These changes in orthophosphate levels could be due to restoration activities such as dredging, pumping of sea water and closing of many surface drains. The Urban Development Authority (UDA) ${ }^{9}$, assumed that pumping sea water, which causes dilution of nutrients and the removal of nutrient enriched sediment would cause a reduction in the nutrient content. Bottom sediment of a water body is important in mobilizing nutrients, especially phosphorous nutrients under anoxic condition $\mathbf{s}^{10}$. Orthophosphate is the main form of phosphorous taken up by the phytoplankton ${ }^{11}$ and this could be a reason for the observed significant positive correlation between Orthophosphate and chlorophyll-a concentrations.

The other nutrients investigated were nitrate and nitrite. An increase in the levels of these nutrients in the restored South-West Lake are evident when compared to previous values of $0.2 \mathrm{mg} \mathrm{L}^{-1}$ of nitrate ${ }^{8}$ and zero level of nitrite $^{12}$. High levels of nitrate, similar to the present levels in South-West Lake were recorded in the distal section of East Lake where the dredging was going-on. According to Munawar ${ }^{13}$, water rich in particulate matter and soil particles is likely to be rich in nitrate. Due to dredging of sediment, soil and other particulate matter can get suspended in water. Therefore, high levels of nitrate in South-West Lake and in the distal portion of East Lake could be a result of dredging activities.

During the present study a highly significant negative correlation was observed between chlorophyll-a and $\mathrm{NO}_{3}-\mathrm{N}$ concentrations. In the surface waters of Beira Lake, blue-green algae constitute a high proportion of the phytoplankton population and contribute heavily to the chlorophyll-a levels. (unpublished thesis-University of Colombo, Study of selected physicochemical parameters and plankton in East Lake and South-West Lake of Beira Lake). Blue- green algae can take in Nitrogen and convert it in to various required forms, through a process known as nitrogen fixations ${ }^{14}$. Therefore $\mathrm{NO}_{3}^{-}$or any other nitrogenous nutrient is not a limiting factor for the growth of blue-green algae. The reason for the negative correlation is not clear. However a similar relationship was observed by $\mathrm{Zafar}^{15}$ where blue-green algae exhibit an inverse relationship with nitrates.

Very high levels of nitrite were recorded only from some stations in East Lake and these stations were confined to two areas of the Lake. The nitrite levels of the other sampling stations of the East Lake and the entire South-West Lake were very low. According to the $\mathrm{UDA}^{8}$ high nitrite levels point to the presence of recent pollution loadings, indicating that the nitrite has not yet been oxidized to nitrate. Therefore the very high nitrite levels in the two areas of East Lake could be due to new nitrite based pollution loads entering those areas during the time of sampling. Very low nitrite levels on the other hand could indicate that no such pollution loads have entered the South-West Lake during the time of sampling.

According to the Biological Environment Survey carried out in 1993 before restoration the $\mathrm{pH}$ level recorded from South-West Lake was 8.47 which was lower than that of East Lake ${ }^{8}$. Therefore the present study, shows an increased pH in South-West Lake which is significantly higher than the level in East Lake. It should be noted that even thought the $\mathrm{pH}$ value of a eutrophic lake is a diurnal phenomenon, this effect is eliminated in comparing the two lakes since both lakes were sampled between $9.00 \mathrm{a} . \mathrm{m}$. to $11.00 \mathrm{a} . \mathrm{m}$. The mean $\mathrm{pH}$ of restored South-West Lake is above the proposed standards of $\mathrm{pH}$ for preservation of fish and other aquatic life, in Sri Lanka, which is between 6 and $8.5^{8}$.

The present study shows an increase in conductivity in the South-West Lake compared to previous studies ${ }^{71}$. However, the conductivity was observed to be significantly lower in South-West Lake compared to East Lake. This same spatial variation was observed by Nahallage and Piyasiri ${ }^{7}$ and $\mathrm{UDA}^{8}$. High conductivity in East Lake is due to sea water intrusion to that part of the lake via lock gates ${ }^{8}$. Increase in electrical conductivity in South-West Lake could be due to pumping of sea water during restoration.

The Secchi depth of South-West Lake in 1993, before restoration was $12 \mathrm{~cm}$ with no spatial variation between South-West and East Lake sections ${ }^{8}$. At present, mean Secchi depth of South-West Lake has increased slightly and significantly higher Secchi depth is recorded in SouthWest Lake compared to East Lake. This increase in Secchi depth could be due to restoration activities in South-West Lake. The spatial variation could be due to both restoration activities and reduction in water transparency in East Lake.

Restoration activities carried out do not seem to be very effective in achieving the objectives of restoration. The green colour of the water continues to impair the attractiveness of the Beira Lake and the reduction of algal booms is therefore, a vital element in restoration of the Beira Lake. In South-West Lake the predominant planktonic algae are filamentous blue-green algae (unpublished thesis-University of Colombo, Study of selected physiochemical paranmeters and plankton in East Lake and South-West Lake of Beira Lake). Filamentous blue-green algae are predominate when there is excess phosphorous concentration ${ }^{10}$. At the same time the 
nutnent contributing to algal blooms in freshwater systems is essentially phosphorous ${ }^{16}$ Therefore the most important nutrient in controlling the present algal bloom in South- West Lake is phosphorous Assocration of phosphorous with sediment is a serious problem in the restoration of shallow, enriched lakes and it can delay the recovery of the lake after reduction of external phosphorous loadings ${ }^{10}$ Therefore, further attention should be given to investigatıng and implementıng more effective methods of controlling internal loading of phosphorous However management of nutrient loadings can result in nutrient limitations that favour one algal type over the other ${ }^{10}$ Therefore it is recommended that all management activities of nutrient loadings for the restoration of Beira Lake should be based on results of scientific studies

\section{Acknowledgment}

The facilities provided by the Sri Lanka Ports Authority and the Department of Zoology of University of Colombo are gratefully acknowledged

\section{Reference}

1 Dissanayaka L \& Pereıra R C (1996) Restoring Betra Lake An Integrated Urban Environmental Planning Experience in Colombo Sri Lanka Colombo Metropolitan Environmental Improvement Programme

2 Silva E I L (2003) Emergence of a Microcystis bloom in an urban water body, Kandy Lake Srı Lanka Current Sctence 85 (6) 723-725

3 Betra Lake Restoratıon Project - Phase I (1999) Presentation at the IESL Auditorium, organized by the National Water Supply and Drainage Board, Galle Road, Rathmalana
4 APHA (1998) Standard methods of exammanon of water and wastewater New York, American Public Health Association, American Waterworks Association and Water Environment Federation

5 OECD (1982) Eutrophication of waters montoring assessment and control Organization for Economic Cooperation and Development, Paris

6 Carlson R E \& Simpson J (1996) A coordinator s guide to volunteer lake montoring methods North American Lake Monitoring Society, Madison, Wisconsin, USA

$7 \quad$ Nahallage C \& Piyasırı S (1997) Trophic status of Beıra Lake Vidyodya Journal of Sclence 7 33-42

8 UDAb (1993b) Betra Lake Restoration Study Summary of the 1993 biological environmental Surveys, Colombo, Urban Development Authority, Sethsiripaya, Battaramulla

9 Urban Development Authority [UDAa] (1993a) Betra Lake Restoration Study Interim Report Components of the Restoration Stratergy, Colombo Urban Development Authority, Sethsiripaya, Battaramulla

10 Ruley E J \& Rusch K A (2002) An assessment of long term post-restoration water quality trends in shallow, sub tropical, urban, hypereutrophic lake Ecological engineering 19 265-280

11 Gunatılaka A (1983) Phosphorous and Phosphatase dynamics in Parakrama Samudra based on diurnal observations In Limnology of Parakrama Samudra (Ed F Schiemer) pp 35-45 Hugue, Dr W Junk Publications

12 Costa H H \& De Silva S S (1978) The Hydrobiology of Colombo (Beira) Lake II- Seasonal variation in physicochemical characterıstics Spolia Zeylanica 32 19-34

13 Munawar M (1968) Limnological studies on Freshwater ponds of Hyderabad-India Hydrobiologia 35 127-159

14 Jeffries M \& Mills, D (1990) Freshwater Ecology Principles and Applications Thurd edition Belharen Press, London

15 Zafar A R (1968) On the ecology of algae in certain fish ponds in Hyderabad, India Hydrobılogia 35, 96-111

16 Kalff J (2002) Limnology Inland water ecosystems Prentice Hall 